\title{
Herbivory in a subtropical seagrass ecosystem: separating the functional role of different grazers
}

\author{
Ameer Ebrahim ${ }^{1}$, Andrew D. Olds ${ }^{1,3, *}$, Paul S. Maxwell ${ }^{1}$, Kylie A. Pitt ${ }^{1}$, \\ Dana D. Burfeind ${ }^{1,2}$, Rod M. Connolly ${ }^{1}$ \\ ${ }^{1}$ Australian Rivers Institute - Coast and Estuaries, School of Environment, Griffith University, Gold Coast, Queensland 4222, \\ Australia \\ ${ }^{2}$ School of Biological Sciences, University of Queensland, St Lucia, Queensland 4072, Australia \\ ${ }^{3}$ Present address: School of Science and Engineering, University of the Sunshine Coast, Maroochydore, Queensland 4558, \\ Australia
}

\begin{abstract}
Seagrass meadows provide many important ecosystem services, but they are threatened by human activities and are in decline globally. In particular, eutrophication arising from human activities promotes algal growth, which negatively affects seagrass. Herbivores consume algae and can, therefore, reduce eutrophication effects, but they may also consume seagrass. Little is known, however, about grazer-epiphyte-seagrass interactions in subtropical seagrass in the Indo-Pacific. We used a 5 wk exclusion experiment to quantify the influence of different grazers in seagrass (dominated by Zostera muelleri) in Moreton Bay, eastern Australia. Our results show that herbivory does indeed affect seagrass-epiphyte dynamics in this region and that different grazers can exert different effects in seagrass ecosystems. In particular, exclusion of small mesograzers (i.e. amphipods and juvenile shrimp) caused epiphyte biomass to increase by up to $233 \%$. Exclusion of medium mesograzers (i.e. small fish and prawns) resulted in increases of up to $10 \%$ in seagrass cover, $53 \%$ in shoot height and $29 \%$ in shoot density. Large mesograzers (i.e. adult fish) and macrograzers (i.e. turtles and dugong) did not appear to play a role in the study system. These results demonstrate that mesograzers can be important in controlling epiphytic algae in subtropical Indo-Pacific seagrass, and show that different mesograzers can affect seagrassepiphyte dynamics in different ways. It is critical that the functional effects of different herbivores be considered when implementing programs for seagrass conservation and restoration.
\end{abstract}

KEY WORDS: Seagrass · Epiphytes $\cdot$ Herbivory $\cdot$ Mesograzers $\cdot$ Fish $\cdot$ Invertebrates $\cdot$ Moreton Bay Australia

Resale or republication not permitted without written consent of the publisher

\section{INTRODUCTION}

Seagrass meadows are important habitats and feeding areas for many organisms and support fisheries production around the world (Heck et al. 2003, Orth et al. 2006, Unsworth \& Cullen 2010). Seagrasses are, however, in decline globally due to the cumulative impacts of disease, declining water quality, dredging, overfishing, invasive species and global climate change (Waycott et al. 2009). Many of these stressors increase algal growth, which can lead to blooms of epiphytic and drift algae and reduce both growth and productivity of seagrasses (Hughes et al. 2004, Baden et al. 2010). Herbivores that remove epiphytic or drift algae have a positive effect on seagrass by increasing light availability, which improves photosynthetic capacity (Hughes et al. 2013, Whalen et al. 2013). Herbivores that graze directly on seagrass, on the other hand, can have negative, positive or variable effects (Heck \& Valentine 2006). For example, heavy grazing that removes substantial biomass can fragment meadows (Fourqurean et al. 2010), 
whereas lighter grazing can stimulate growth and productivity (Valentine et al. 1997, Christianen et al. 2012). Grazers may also have a more variable influence on seagrass by selectively removing particular species, which can alter the composition of seagrass assemblages (Preen 1995, Burkholder et al. 2012). In order to effectively manage seagrass ecosystems and their accompanying services, it is imperative that studies seek to quantify the functional importance of different grazers.

Our understanding of grazing effects on seagrass is complicated by the diversity of herbivores, which include macrograzers (i.e. dugongs, manatees, turtles and waterfowl) and mesograzers (i.e. fish and invertebrates) (Heck \& Valentine 2006). It is also further compounded by substantial variation in grazing rates and the role of different grazers in different parts of the world (see reviews by Hughes et al. 2004, Heck \& Valentine 2006, Valentine \& Duffy 2006). Grazing studies from different locations and latitudes have tended to focus on different groups of grazers. Tropical and subtropical studies emphasise the importance of direct grazing on seagrass by fish, urchins, and turtles (e.g. Kirsch et al. 2002, Alcoverro \& Mariani 2004, Verges et al. 2011, Christianen et al. 2012), whereas temperate zone studies (with a strong focus on northern Europe) emphasise the role of invertebrate mesograzers (i.e. crustaceans and gastropods), which feed on ephemeral and epiphytic algae and rarely consume seagrass directly (e.g. Hillebrand et al. 2000, Moksnes et al. 2008, Svensson et al. 2012).

Until the end of the 20th century, most studies of epiphyte-grazer interactions were restricted to cooler temperate waters (Heck \& Valentine 2006), but there is a growing body of work on tropical and subtropical seagrasses (e.g. Klumpp et al. 1992, Peterson et al. 2007, Drury McCall et al. 2009, Myers \& Heck 2013). However, seagrass grazing has not been widely studied on the east coast of Australia, with the exception of studies on large macrograzers (i.e. turtles and dugong) (e.g. Preen 1995, BrandGardner et al. 1999, Aragones \& Marsh 2000, KuiperLinley et al. 2007). The focus of seagrass studies in this region has instead been on the effects of eutrophication and sedimentation (e.g. Carruthers et al. 2002, Waycott et al. 2005); with an emphasis, in subtropical waters, on understanding the effects of turbidity and nutrient processing (e.g. Abal \& Dennison 1996, Udy \& Dennison 1997, Longstaff \& Dennison 1999). It is now widely appreciated, however, that the impacts of eutrophication commonly interact with the effects of grazing in seagrass ecosystems (Baden et al. 2010, Hughes et al. 2013, Whalen et al.
2013). It is logical, therefore, to expect that grazing might be important for seagrass development on the east coast of Australia, but this hypothesis has not yet been tested.

We conducted a field experiment to evaluate the role of different grazers in structuring seagrass and epiphyte dynamics in Moreton Bay, eastern Australia. Moreton Bay contains extensive seagrass (dominated by Zostera muelleri) (Roelfsema et al. 2013), supports abundant and diverse seagrass grazers (Tibbetts \& Connolly 1998), and receives high nutrient loads from the adjacent urbanised catchment (Leigh et al. 2013). This situation is now typical in eastern Australia (Wolanski 2014), and this location was selected so that results would be relevant to other subtropical bays in the region. Based on the results of subtropical studies from elsewhere (Kirsch et al. 2002, Burkholder et al. 2012, Myers \& Heck 2013), we hypothesized that: (1) large mesograzers (i.e. adult fish) would dominate direct grazing of seagrass and that experimental exclusion would increase seagrass growth, cover, shoot density and shoot height, and (2) small mesograzers (i.e. amphipods and juvenile shrimp) would dominate grazing of epiphytes and that experimental exclusion would increase epiphyte biomass.

\section{MATERIALS AND METHODS}

\section{Quantifying the roles of different herbivores}

The contribution of mesograzers to seagrass and epiphyte dynamics was quantified using a manipulative exclusion experiment. The experiment was conducted over the austral summer (2012-2013) to maximize herbivore abundance and, therefore, herbivory in the study area. Given the difficulty in maintaining large numbers of exclusion cages over long periods of deployment, the experiment was restricted to a single location, Waterloo Bay $\left(27^{\circ} 15^{\prime} \mathrm{S}, 153^{\circ} 15^{\prime} \mathrm{E}\right)$, in western Moreton Bay. This location was selected because it receives high nutrient loads (Gibbes et al. 2014) (mean concentrations over the study period: total nitrogen $0.37 \mathrm{mg} \mathrm{l}^{-1}$; total phosphorus $0.05 \mathrm{mg}$ $\mathrm{l}^{-1}$ ), has abundant mesograzers (see Table $\mathrm{S} 1$ in the Supplement at www.int-res.com/articles/suppl/m511 p083_supp.pdf) (Skilleter et al. 2005), and supports a high coverage ( $80 \%$ ) of homogeneous Zostera muelleri, which is typically free from drift algae (Skilleter et al. 2005, Maxwell et al. 2014).

The experiment included 70 plots of seagrass: 10 control plots that did not exclude herbivores (Treatment 1), 40 herbivore exclusion cages (Treatments 2 
Table 1. Summary of herbivore exclusion treatments: mesh size of cage cover and the type and size of grazers manipulated by each treatment. Macrograzers: turtles, dugong, waterbirds; large mesograzers ( $>3 \mathrm{~cm}$ body depth): adult fish; medium mesograzers $(1-3 \mathrm{~cm})$ : juvenile fish, shrimp, prawns; small mesograzers $(<1 \mathrm{~cm})$ : amphipods, juvenile shrimp and prawns

\begin{tabular}{|llll|}
\hline $\begin{array}{l}\text { Treatment } \\
\text { number }\end{array}$ & Mesh size of cage cover & Permitted access & Excluded access \\
\hline 1 & Uncaged (control) & All grazers & None \\
2 & $6 \mathrm{~cm}$ & Mesograzers & Macrograzers \\
3 & $3 \mathrm{~cm}$ & Medium mesograzers & Macrograzers, large mesograzers \\
4 & $1 \mathrm{~cm}$ (no insecticide) & Small mesograzers & Macrograzers, large and medium mesograzers \\
5 & $1 \mathrm{~cm}$ (with insecticide) & No grazers & All grazers \\
6 & $3 \mathrm{~cm}$ (partial cover; procedural control) & All grazers & None \\
7 & $1 \mathrm{~cm}$ (partial cover; procedural control) & All grazers & None \\
\hline
\end{tabular}

to 5), and 20 procedural control cages (Treatments 6 to 7 ) (Table 1), which were monitored immediately prior to deployment of cages and then weekly for $5 \mathrm{wk}$. Ten replicate quadrats were assigned to each treatment. The 4 herbivore exclusion treatments excluded different types and sizes of herbivores. Exclusion quadrats consisted of a single cage made from a steel frame (length $\times$ width $\times$ height: $0.5 \times 0.4 \times$ $0.28 \mathrm{~m}$ ), which was covered in monofilament mesh on the sides and top surfaces, but not on the bottom (following Olds et al. 2012). Cages were anchored to the substrate using pegs and weights to prevent organisms from moving under the frame.

Quadrats that did not exclude any grazers (Treatment 1) had a base, but no frame or mesh. Cages that excluded grazers (Treatments 2 to 5 ) were fitted with monofilament mesh of variable sizes $(6,3$ and $1 \mathrm{~cm}$, see Table 1) to permit access by grazers of different sizes. Cages that excluded all grazers (Treatment 5) had a $1 \mathrm{~cm}$ mesh and were also treated with the insecticide carbaryl (Poore et al. 2009, Cook et al. 2011, Whalen et al. 2013). The insecticide was deployed in slow-release bricks in the field, which were formed by incorporating carbaryl into dental plaster (Poore et al. 2009). The chosen cage dimensions and mesh sizes were informed by previous exclusion studies (Cook et al. 2011, Planes et al. 2011). Ten replicates of each of 2 types of procedural control cages (Treatments 6 and 7 , with 3 and $1 \mathrm{~cm}$ mesh sizes, respectively) were also deployed for the duration of the study, to control for potential caging artifacts. These controls, which had mesh on only half of each side, permitted grazers to access seagrass and epiphytes, but exerted similar effects to completely mesh-covered cages on light and water motion.

Treatment plots were interspersed over seagrass at the study area and were separated by at least $2 \mathrm{~m}$ to prevent the insecticide from affecting the other cages (Whalen et al. 2013). To minimize potential confound- ing effects of cages on light and water motion, the roofs and walls of cages were cleaned weekly to remove accumulated debris and algae (following Planes et al. 2011). The effect of excluding different grazers on seagrass and epiphyte dynamics was examined by quantifying seagrass growth, cover, shoot density, shoot height and epiphyte biomass in all treatment quadrats. The total number of seagrass shoots and percentage of each quadrat covered by each species was recorded by a single observer (Duarte \& Kirkman 2001). Average shoot height was measured by grasping a large handful of seagrass leaves, ignoring the tallest $20 \%$ (Duarte \& Kirkman 2001), and measuring the height from the sediment to the top of the remaining $80 \%$ of leaves. This technique was repeated 5 times in each quadrat and the mean shoot height was calculated. Seagrass growth was quantified using the pin-hole method (Zieman 1974, Westera \& Lavery 2006). Three different shoots in each exclusion cage were marked using a needle at the start of the experiment; these were then harvested at the completion of the experiment (i.e. after $5 \mathrm{wk}$ ) and growth was measured as the distance from the upper section of the leaf sheath to the pin-hole mark. Epiphyte biomass was quantified as the dry weight of epiphytes scraped from seagrass blades (Kendrick \& Lavery 2001). Ten $Z$. muelleri leaves were collected from each quadrat each week, washed gently to remove inorganic material, and epiphytes were then removed with a razor and oven-dried at $60^{\circ} \mathrm{C}$ for $48 \mathrm{~h}$. To prevent the weekly collection of seagrass (for epiphyte sampling) from affecting the other seagrass variables, $Z$. muelleri leaves were only collected from one quarter of each quadrat. This sector was not included when quantifying the other seagrass variables. Weekly measurements of seagrass and epiphyte variables were taken quickly, and where possible through the exclusion mesh, to limit both the duration and extent of disturbance to caged treatments. 
The insecticide carbaryl is a tested and effective deterrent of arthropods in seagrass, but has negligible effects on other taxa including algae (e.g. Poore et al. 2009, Cook et al. 2011, Whalen et al. 2013). To ensure its effectiveness in this study we quantified the background density of arthropods in the seagrass meadow prior to commencing the experiment (inside five $0.5 \times$ $0.4 \mathrm{~m}$ quadrats). Arthropod densities were then quantified on 3 occasions after cage deployment (at 1, 7 and $14 \mathrm{~d}$ ). To minimize disturbance to experimental treatments, all arthropods were collected carefully by hand from inside five $0.5 \times 0.4 \mathrm{~m}$ cages containing the insecticide, and from inside 5 replicate $0.5 \times 0.4 \mathrm{~m}$ quadrats, which were haphazardly placed in the seagrass meadow (at least $2 \mathrm{~m}$ from any other quadrat). The insecticide was replaced every $7 \mathrm{~d}$.

\section{Quantifying herbivore abundance}

The abundance, size and identity of mesograzers in the seagrass meadow was quantified at the end of the cage exclusion experiment using a small seine net $(6 \times 2 \mathrm{~m}$ with a $2 \mathrm{~mm}$ mesh) and small quadrats $\left(0.5 \mathrm{~m}^{2}\right)$, (Skilleter et al. 2005, Cook et al. 2011, Davie 2011). Nektonic mesograzers were collected from 5 replicate seine net samples. Nets were hauled for $25 \mathrm{~m}$ parallel to the shoreline with a constant mouth width of $4 \mathrm{~m}$, sampling a total area of $100 \mathrm{~m}^{2}$ for each haul (Skilleter et al. 2005). Benthic mesograzers were collected from 5 replicate and haphazardly placed quadrats (Cook et al. 2011).

\section{Data analysis}

The effect of excluding different grazers on seagrass and epiphyte dynamics was evaluated using generalized linear mixed models (GLMMs) with repeated measures (Venables \& Dichmont 2004). Analyses examined changes in epiphyte biomass, seagrass cover, shoot density and shoot height in different exclusion treatments over time (exclusion treatment and time were fixed orthogonal factors). Post hoc least significant difference (LSD) tests were used to interrogate significant results and determine which exclusion treatments differed over time. Data did not require transformation as assumptions of GLMMs were met.

To test whether seagrass growth differed among exclusion treatments, data were analysed with 1-way Analysis of Variance (ANOVA). The assumption of homoscedasticity was met.

\section{RESULTS}

\section{Roles of different herbivores}

Seagrass and epiphytic algae were both influenced by the exclusion of herbivores but responded in different ways depending on which grazers were excluded. The biomass of algal epiphytes on seagrass in Treatment 5, from which all herbivores were excluded, increased rapidly (from $\sim 0.03$ to $0.10 \mathrm{~g}$ per blade), and differed from all other treatments after 1 wk (Fig. 1, Table 2, Table S2 in the Supplement). Epiphyte biomass remained low ( 0.01 to $0.03 \mathrm{~g}$ per blade) in all other treatments, including the control cages, and did not differ among treatments (Fig. 1). In Treatment 5, the insecticide used removed all arthropod mesograzers within $24 \mathrm{~h}$ of deployment and this effect was maintained throughout the experiment. The density (mean $\pm \mathrm{SE}$ ) of arthropod mesograzers was $90 \pm 27$ ind. $\mathrm{m}^{-2}$ before the experiment; zero in Treatment 5 during the experiment; and $104 \pm 23$ ind. $\mathrm{m}^{-2}$ elsewhere in the meadow during the experiment.

Seagrass cover in both Treatments 4 and 5 increased gradually over time (from $\sim 75$ to $85 \%$ and from $\sim 80$ to $90 \%$, respectively), and was greater than all other treatments after 5 wk of deployment (Fig. 1, Tables 2 \& S3 in the Supplement). Seagrass cover did not differ among the other 5 treatments (Fig. 1). Shoot height also increased over time in both Treatments 4 and 5 (from $\sim 11$ to $14 \mathrm{~cm}$ and from $\sim 9.5$ to $14.5 \mathrm{~cm}$, respectively), and was greater than in all other treatments after 3 wk of deployment (Fig. 1, Tables 2 \& S4 in the Supplement). Shoot height remained fairly low and constant $(6$ to $10 \mathrm{~cm}$ ) in the other 5 treatments, and did not differ among them (Fig. 1). Shoot density followed the same trend of rising over time in both Treatments 4 and 5 (from $\sim 90$ to 100 shoots per $0.2 \mathrm{~m}^{2}$ and from $\sim 85$ to 110 shoots per $0.2 \mathrm{~m}^{2}$, respectively), and was greater than in all other treatments after 3 wk of deployment (Fig. 1, Tables 2 \& S5 in the Supplement). Shoot density varied among the other 5 treatments, but was generally lower in Treatment 1 than in Treatments 2 or 3 (Fig. 1). Seagrass growth was constant (approximately $1 \mathrm{~cm}$ in length) and did not differ among treatments (Table 2).

\section{Herbivore abundance}

The herbivore assemblage was dominated by 3 sizes of mesograzers: (1) small mesograzers (primarily amphipods), which were only excluded from Treatment 5; (2) medium mesograzers (i.e. juvenile 

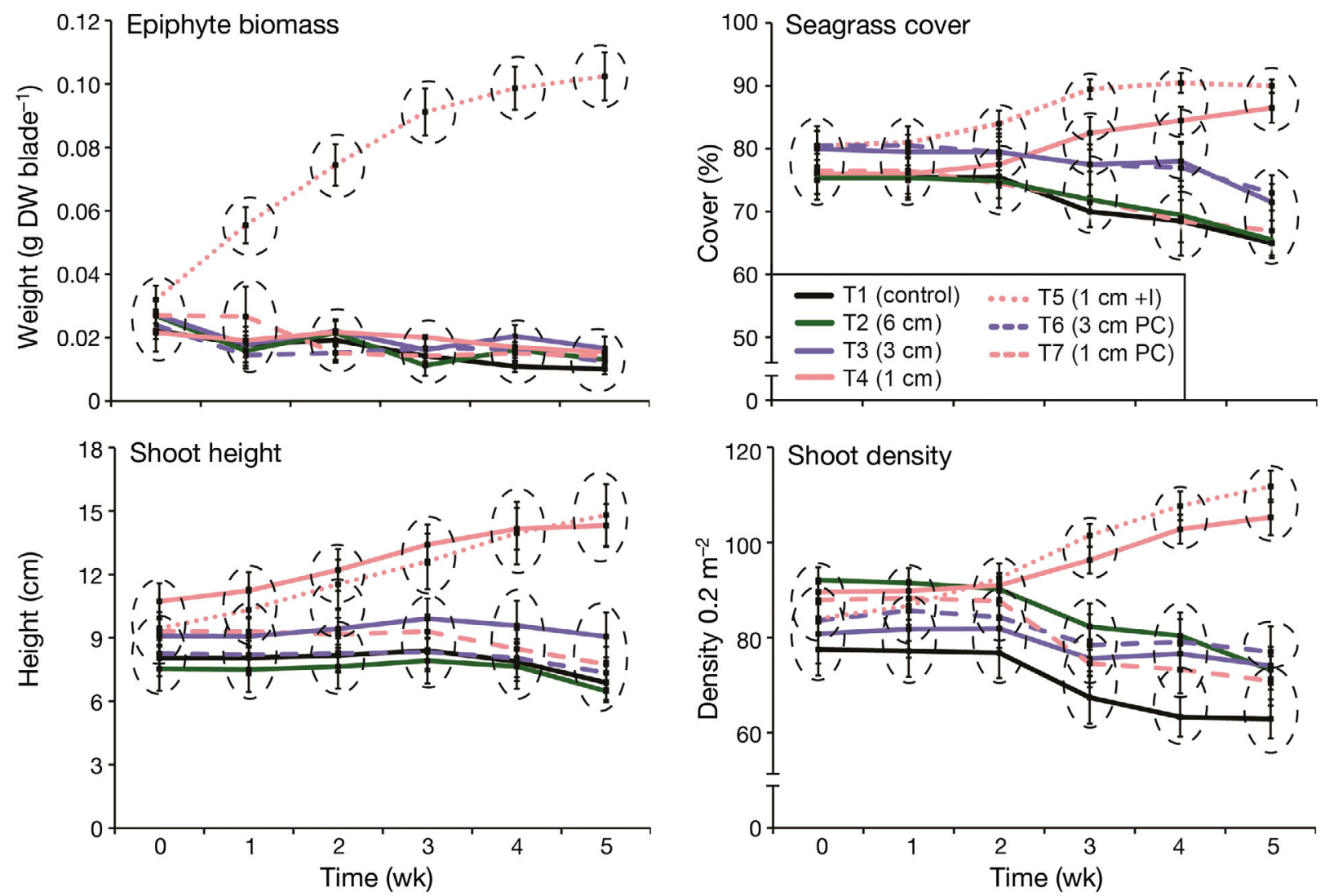

Fig. 1. Temporal (weekly) changes in epiphyte and seagrass variables (mean \pm SE) under each herbivore exclusion treatment. See Table 1 for descriptions of treatments (T1-T7, mesh size of cage cover in parentheses, +I: with insecticide, PC: procedural control). Ellipses show the results of least significant difference (LSD) post hoc tests: overlapping ellipses encompass groups of one or more means in each week that were not significantly different from each other $(p>0.05)$; lack of overlap identifies groups of means that were significantly different

fish, shrimp and prawns), which were excluded from Treatments 4 and 5; and (3) large mesograzers (i.e. adult fish), which were excluded from Treatments 3 , 4 and 5. Small mesograzers were dominated by amphipods (Fig. 2). Medium mesograzers were dominated by eastern trumpeter Pelates sexlineatus, fanbellied leatherjacket Monacanthus chinensis and tiger prawns Penaeus esculentus (Fig. 2). Large mesograzers were not common, but were dominated by fan-bellied leatherjackets, dusky leatherjackets Paramonacanthus otisensis and yellowfin bream

Table 2. Summary of results (p-values) of generalized linear mixed model (GLMM) and ANOVA analyses of temporal changes in epiphyte and seagrass variables in response to herbivore exclusion treatments. df: degrees of freedom; E: experimental treatment; T: time; NA: not applicable

\begin{tabular}{|lrrrrrc|}
\hline Factor & df & $\begin{array}{c}\text { Epiphyte } \\
\text { biomass }\end{array}$ & $\begin{array}{c}\text { Seagrass } \\
\text { cover }\end{array}$ & $\begin{array}{c}\text { Shoot } \\
\text { height }\end{array}$ & $\begin{array}{c}\text { Shoot } \\
\text { density }\end{array}$ & $\begin{array}{c}\text { Seagrass } \\
\text { growth }\end{array}$ \\
\hline $\mathrm{E}$ & 6 & $<0.001$ & 0.011 & $<0.001$ & $<0.001$ & $\begin{array}{c}<.065 \\
\mathrm{~T}\end{array}$ \\
$\mathrm{E} \times \mathrm{T}$ & 5 & 0.334 & $<0.001$ & $<0.001$ & $<0.001$ & $\mathrm{NA}$ \\
& 30 & $<0.001$ & $<0.001$ & $<0.001$ & $<0.001$ & $\mathrm{NA}$ \\
\hline
\end{tabular}

Acanthopagrus australis (Fig. 2). Dugongs and turtles frequent the area but were not observed during the experiment, nor was there evidence of recent feeding by macrograzers.

\section{DISCUSSION}

Herbivory is an important process in seagrass ecosystems (Heck \& Valentine 2006), but we know little about the role of mesograzers in the Indo-Pacific region. Our results show that mesograzers do indeed affect seagrassepiphyte dynamics in this region, and demonstrate that different mesograzers can exert different functional effects on subtropical seagrass and epiphytes. The exclusion of small arthropod mesograzers correlated with a $233 \%$ increase in epiphyte biomass on seagrass leaves over $5 \mathrm{wk}$. In contrast, the exclusion of medium- 

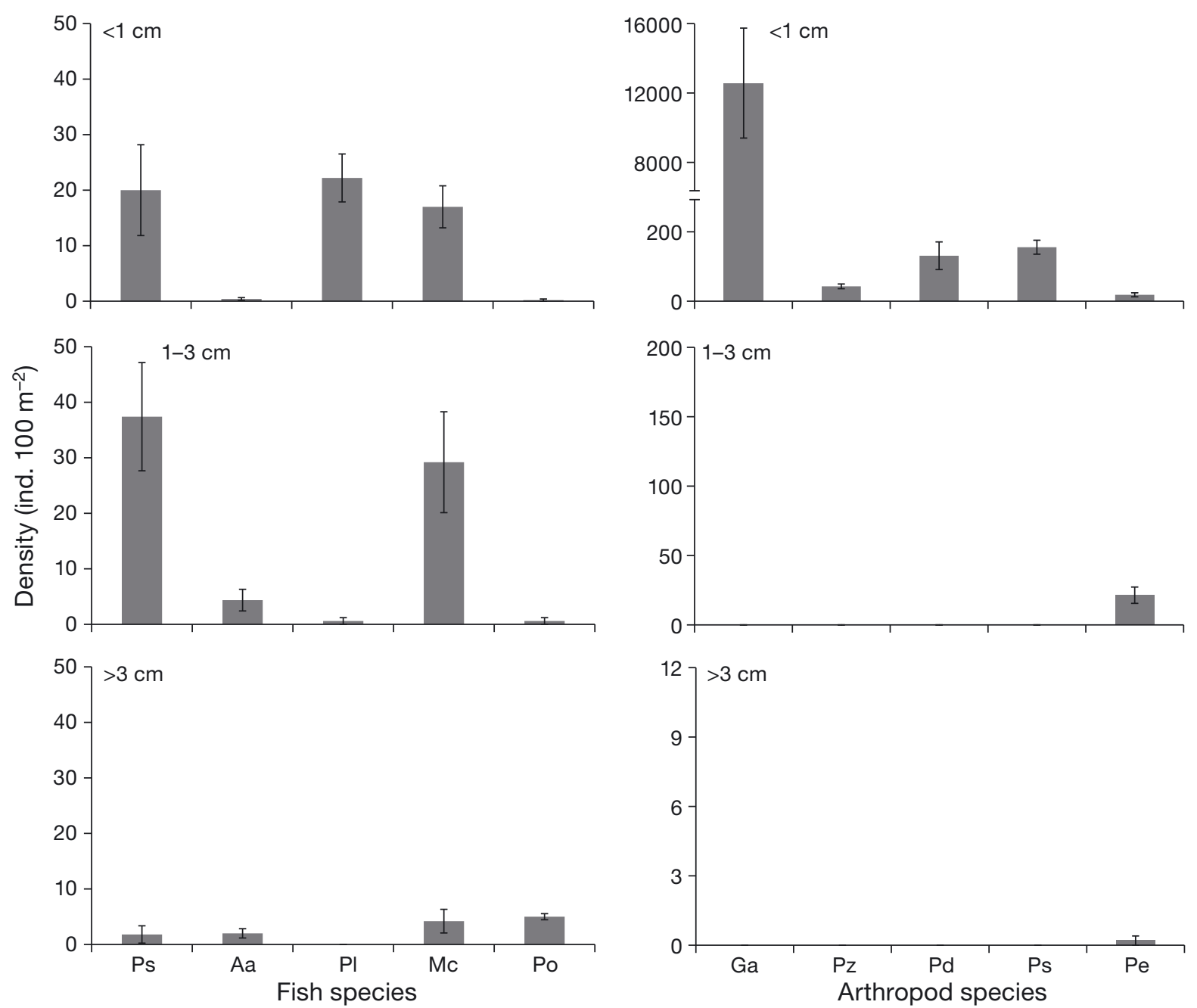

Fig. 2. Density (mean $\pm \mathrm{SE}$ ) of herbivorous fish (left panels) and arthropods (right panels) collected using seine nets and quadrats at the study site (see 'Materials and methods'). Fish - Ps: Pelates sexlineatus; Aa: Acanthopagrus australis; Pl: Petroscirtes lupus; Mc: Monacanthus chinensis; Po: Paramonacanthus otisensis. Arthropods-Ga: Gammarid amphipods; Pz: Phycomenes zostericola; Pd: Palaemon debilis; Ps: Palaemon serenus; Pe: Penaeus esculentus. Size classes are based on the body depth $(\mathrm{cm})$ of organisms. Note different $y$-axis scales

sized mesograzers correlated with increases in seagrass cover (up to $10 \%$ ), shoot height (up to $53 \%$ ) and shoot density (up to $29 \%$ ). These results provide strong support for our second hypothesis (i.e. that small arthropod mesograzers would regulate seagrass epiphytes), but do not support our first hypothesis (that large fish mesograzers would affect seagrass dynamics).

The response of seagrass epiphytes to the exclusion of small arthropod mesograzers (and not to the exclusion of larger herbivores) suggests that these organisms (primarily amphipods and small shrimp) were largely responsible for regulating epiphytes on seagrass blades. This finding concurs with the results of several recent studies in the USA and Australia, which have examined the impact on seagrass epi- phytes of experimental removal of herbivorous arthropods. For example, Myers \& Heck (2013), Whalen et al. (2013) and Cook et al. (2011) all determined that the removal of small arthropod mesograzers (also primarily amphipods) leads to large increases in the biomass of seagrass epiphytes (i.e. up to $70 \%$ over $10 \mathrm{wk}, 447 \%$ over $3.5 \mathrm{wk}$ and $25 \%$ over $7 \mathrm{wk}$, respectively in the 3 studies).

With greater epiphyte loads it would seem logical to expect a concomitant reduction in seagrass biomass (Myers \& Heck 2013), but this does not always occur (Cook et al. 2011). Our results show that after 5 wk the increased biomass of epiphytes had not negatively affected seagrass growth. This was possibly influenced by the short duration of the experiment and the tolerance of Zostera muelleri to low 
light conditions. For example, Abal et al. (1994) demonstrated experimentally that $Z$. muelleri can survive for at least $55 \mathrm{~d}$ at just $5 \%$ of surface light intensity. However, rather than declining when subjected to higher epiphyte loads, seagrass cover, shoot height and shoot density all increased following the exclusion of small arthropod mesograzers. In fact, the response of seagrass was identical in both treatments that excluded medium-sized mesograzers (i.e. Treatments 4 and 5, with and without insecticide). This suggests that small arthropod mesograzers regulate seagrass epiphytes in the study area but exert little direct influence on seagrass. This result also indicates that the observed epiphyte loads have little effect on the above-ground properties of seagrass, and emphasizes that direct consumption by small and medium-sized mesograzers may be more important than previously recognized.

The positive response of seagrass variables to the exclusion of medium-sized mesograzers (in treatments both with and without insecticide) indicates that small fish and invertebrates may play an important role in regulating seagrass dynamics. Indeed, fish and invertebrates are recognized as important direct grazers of seagrass in the Indo-Pacific region (e.g. Alcoverro \& Mariani 2004, Unsworth et al. 2007) and elsewhere (e.g. Armitage \& Fourqurean 2006, Gullström et al. 2011, Verges et al. 2011), but the majority of studies have focused on the effects of large fish and urchins. Our results show that seagrass cover, shoot height and shoot density increased when the access of small fish and invertebrates was restricted, which suggests that seagrass may have been released from the top-down regulation by herbivores within this group. Eastern trumpeter, leatherjackets, juvenile yellowfin bream and tiger prawns were the dominant medium-sized mesograzers in the seagrass meadow. These species can be important seagrass grazers (Table S1), but they are largely omnivorous and many also directly consume the arthropod mesograzers (i.e. amphipods and small shrimp) that appear to regulate seagrass-epiphyte dynamics in the study area (e.g. Warburton \& Blaber 1992, O'Brien 1994, Sanchez-Jerez et al. 2002, Hadwen et al. 2007). This omnivory adds a level of complexity to seagrass food webs that complicates both the trophic relationships among herbivores (particularly since smaller herbivores can become predators with age) and their functional impact in seagrass ecosystems (Heck et al. 2000, Moksnes et al. 2008). These effects can be further compounded by changes to seagrass food webs, which result from the cascading impact of harvesting higher order consumers
(Baden et al. 2012, Hughes et al. 2013). However, the rapid increase in seagrass epiphyte loads with exclusion of small arthropods suggests that these mesograzers are naturally abundant in the study area and may experience little top-down regulation by predators (sensu Tibbetts \& Connolly 1998, Skilleter et al. 2005).

The potential broad importance of seagrass mesograzers has typically been overlooked on the east coast of Australia. Our findings demonstrate that mesograzers can indeed be key herbivores in subtropical seagrass ecosystems in the region. This study was, however, restricted to a single location in western Moreton Bay, which was known a priori to receive relatively high nutrient loads (Burfeind \& Udy 2009, Leigh et al. 2013, Maxwell et al. 2014) and support abundant fish and invertebrate mesograzers (Skilleter et al. 2005). This type of urbanized seascape is now common in subtropical bays in eastern Australia (Wolanski 2014) and our results are, therefore, of broad relevance across this region. The apparent lack of importance of large fish grazers and macrograzers (i.e. dugong and turtle) in this experiment is, however, likely to reflect the relatively low abundance of these organisms in the study area. Larger herbivorous fish and macrograzers do occur in western Moreton Bay, but are more abundant in eastern Moreton Bay and in local marine reserves, where their role as direct seagrass grazers is probably greater (Kuiper-Linley et al. 2007, Olds et al. 2012). It will be important, therefore, to evaluate the combined roles of both mesograzers and macrograzers in locations that support more extensive populations of large herbivorous fish, turtles and dugong, such as marine reserves (Pillans et al. 2007, Olds et al. 2012) or recognised dugong and turtle aggregation areas (Brand-Gardner et al. 1999, Lanyon 2003).

Herbivory is clearly an important process in seagrass ecosystems. It affects seagrass-epiphyte dynamics and can offset the impacts of eutrophication. Our findings highlight the role that mesograzers play in regulating epiphytic algae in subtropical IndoPacific seagrass meadows. We demonstrated empirically that different mesograzers can exert different functional effects on seagrass and seagrass epiphytes. The different functions performed by mesograzers have important implications for seagrass growth and productivity, and the capacity of seagrass to cope with disturbance. It will be important, therefore, to quantify the response and different functional effects of seagrass herbivores to eutrophication and the implementation of management actions aimed at improving seagrass health and productivity. 
Acknowledgements. We thank T. Martin and M. St. Ange for field and laboratory assistance, and T. Stevens and S. Albert for improving the manuscript. The research was supported by Australian Rivers Institute; R.M.C. and K.A.P. were supported by the Australian Research Council.

\section{LITERATURE CITED}

Abal EG, Dennison WC (1996) Seagrass depth range and water quality in southern Moreton Bay, Queensland. Mar Freshw Res 47:763-771

> Abal EG, Loneragan N, Bowen P, Perry CJ, Udy JW, Dennison WC (1994) Physiological and morphological responses of the seagrass Zostera capricorni Aschers to light intensity. J Exp Mar Biol Ecol 178:113-129

> Alcoverro T, Mariani S (2004) Patterns of fish and sea urchin grazing on tropical Indo-Pacific seagrass beds. Ecography 27:361-365

Aragones L, Marsh H (2000) Impact of dugong grazing and turtle cropping on tropical seagrass communities. Conserv Biol 5:277-288

> Armitage AR, Fourqurean JW (2006) The short-term influence of herbivory near patch reefs varies between seagrass species. J Exp Mar Biol Ecol 339:65-74

Baden S, Boström C, Tobiasson S, Arponen H, Moksnes PO (2010) Relative importance of trophic interactions and nutrient enrichment in seagrass ecosystems: a broadscale field experiment in the Baltic-Skagerrak area. Limnol Oceanogr 55:1435-1448

> Baden S, Emanuelsson A, Pihl L, Svensson CJ, Åberg P (2012) Shift in seagrass food web structure over decades is linked to overfishing. Mar Ecol Prog Ser 451:61-73

Brand-Gardner SJ, Lanyon JM, Limpus CJ (1999) Diet selection by immature green turtles, Chelonia mydas, in subtropical Moreton Bay, south-east Queensland. Aust J Zool 47:181-191

> Burfeind DD, Udy JW (2009) The effects of light and nutrients on Caulerpa taxifolia and growth. Aquat Bot 90: 105-109

Burkholder DA, Heithaus MR, Fourqurean JW (2012) Feeding preferences of herbivores in a relatively pristine subtropical seagrass ecosystem. Mar Freshw Res 63: 1051-1058

Carruthers TJB, Dennison WC, Longstaff BJ, Waycott M, Abal EG, McKenzie LJ, Long WJL (2002) Seagrass habitats of Northeast Australia: models of key processes and controls. Bull Mar Sci 71:1153-1169

Christianen MJA, Govers LL, Bouma TJ, Kiswara W, Roelofs JGM, Lamers LPM, van Katwijk MM (2012) Marine megaherbivore grazing may increase seagrass tolerance to high nutrient loads. J Ecol 100:546-560

> Cook K, Vanderklift MA, Poore AGB (2011) Strong effects of herbivorous amphipods on epiphyte biomass in a temperate seagrass meadow. Mar Ecol Prog Ser 442:263-269

Davie P (2011) Wild guide to Moreton Bay and adjacent coasts. Queensland Museum, Brisbane

> Drury McCall D, Rakocinski CF, Pinckney JL (2009) Effects of grass shrimp versus nutrient addition on epiphytic algae associated with the ephemeral widgeon grass Ruppia maritima. Mar Ecol Prog Ser 379:151-162

Duarte CM, Kirkman H (2001) Methods for the measurement of seagrass abundance and depth distribution. In: Short FT, Coles RG (eds), Global seagrass research methods. Elsevier, Amsterdam, p 141-153
Fourqurean JW, Manuel S, Coates KA, Kenworthy WJ, Smith SR (2010) Effects of excluding sea turtle herbivores form a seagrass bed: overgrazing may have led to loss of seagrass meadows in Bermuda. Mar Ecol Prog Ser 419:223-232

Gibbes B, Grinham A, Neil D, Olds A and others (2014) Moreton Bay and its estuaries: a sub-tropical system under pressure from rapid population growth. In: Wolanski E (ed) Estuaries of Australia in 2050 and beyond. Series 'Estuaries of the world', Springer, Dordrecht, p 203-222

> Guest MA, Connolly RM, Loneragan NR (2003) Seine nets and beam trawls compared by day and night for sampling fish and crustaceans in shallow seagrass habitat. Fish Res 64:185-196

Gullström M, Berkström C, Öhman MC, Bodin M, Dahlberg M (2011) Scale-dependent patterns of variability of a grazing parrotfish (Leptoscarus vaigiensis) in a tropical seagrass-dominated seascape. Mar Biol 158:1483-1495

> Hadwen WL, Russell GL, Arthington AH (2007) Gut contentand stable isotope-derived diets of four commercially and recreationally important fish species in two intermittently open estuaries. Mar Freshw Res 58:363-375

Heck KL Jr, Valentine JF (2006) Plant-herbivore interactions in seagrass meadows. J Exp Mar Biol Ecol 330: 420-436

Heck KL Jr, Pennock JR, Valentine JF, Coen LD, Sklenar SA (2000) Effects of nutrient enrichment and small predator density on seagrass ecosystems: an experimental assessment. Limnol Oceanogr 45:1041-1057

Heck KL Jr, Hays G, Orth RJ (2003) Critical evaluation of the nursery hypothesis for seagrass meadows. Mar Ecol Prog Ser 253:123-136

Hillebrand H, Worm B, Lotze HK (2000) Marine microbenthic community structure regulated by nitrogen loading and grazing pressure. Mar Ecol Prog Ser 204:27-38

> Hughes AR, Bando KJ, Rodriguez LF, Williams SL (2004) Relative effects of grazers and nutrients on seagrasses: a meta-analysis approach. Mar Ecol Prog Ser 282:87-99

> Hughes BB, Eby R, Van Dyke E, Tinker MT, Marks CI, Johnson KS, Wasson K (2013) Recovery of a top predator mediates negative effects on seagrass. Proc Natl Acad Sci USA 110:15313-15318

Kendrick GA, Lavery PS (2001) Assessing biomass, assemblage structure and production of algal epiphytes on seagrasses. In: Short FT, Coles RG (eds) Global seagrass research methods. Elsevier, Amsterdam, p 199-222

> Kirsch KD, Valentine JF, Heck KL Jr (2002) Parrotfish grazing on turtlegrass Thalassia testudinum: evidence for the importance of seagrass consumption in food web dynamics of the Florida Keys National Marine Sanctuary. Mar Ecol Prog Ser 227:71-85

Klumpp DW, Salita-Espinosa JS, Fortes MD (1992) The role of epiphytic periphyton and macroinvertebrate grazers in the trophic flux of a tropical seagrass community. Aquat Bot 43:327-349

> Kuiper-Linley M, Johnson CR, Lanyon JM (2007) Effects of simulated green turtle regrazing on seagrass abundance, growth and nutritional status in Moreton Bay, south-east Queensland, Australia. Mar Freshw Res 58:492-503

> Lanyon JM (2003) Distribution and abundance of dugongs in Moreton Bay, Queensland, Australia. Wildl Res 30: 397-409

Leigh C, Burford MA, Connolly RM, Olley JM and others (2013) Science to support management of receiving 
waters in an event-driven ecosystem: from land to river to sea. Water 5:780-797

Longstaff BJ, Dennison WC (1999) Seagrass survival during pulsed turbidity events: the effects of light deprivation on the seagrasses Halodule pinifolia and Halophila ovalis. Aquat Bot 65:105-121

Maxwell PM, Burfeind DD, Pitt KA, Olds AD, Babcock RC, Connolly RM (2014) Phenotypic plasticity promotes persistence following extreme events: physiological and morphological responses of seagrass to flooding. J Ecol 102:54-64

Moksnes PO, Gullström M, Tryman K, Baden S (2008) Trophic cascades in a temperate seagrass community. Oikos 117:763-777

> Myers JA, Heck KL Jr (2013) Amphipod control of epiphyte load and its concomitant effects on shoalgrass Halodule wrightii biomass. Mar Ecol Prog Ser 483:133-142

O'Brien CJ (1994) Ontogenetic changes in the diet of juvenile brown tiger prawns Penaeus esculentus. Mar Ecol Prog Ser 112:195-200

Olds AD (2003) The effects of proximity to mangroves and structural complexity of seagrass on nekton communities in a subtropical estuarine environment. Honours thesis. University of Queensland, Brisbane

Olds AD, Pitt KA, Maxwell PS, Connolly RM (2012) Synergistic effects of reserves and connectivity on ecological resilience. J Appl Ecol 49:1195-1203

> Orth RJ, Carruthers TJB, Dennison WC, Duarte CM and others (2006) A global crisis for seagrass ecosystems. Bioscience 56:987-996

> Peterson BJ, Frankovich TA, Zieman JC (2007) Response of seagrass epiphyte loading to field manipulations of fertilization, gastropod grazing and leaf turnover rates. J Exp Mar Biol Ecol 349:61-72

> Pillans S, Ortiz J, Pillans RD, Possingham HP (2007) The impact of marine reserves on nekton diversity and community composition in subtropical eastern Australia. Biol Conserv 136:455-469

Planes S, Raventos N, Ferrari B, Alcoverro T (2011) Fish herbivory leads to shifts in seagrass Posidonia oceanica investments in sexual reproduction. Mar Ecol Prog Ser 431:205-213

> Poore AGB, Campbell AH, Steinberg PD (2009) Natural densities of mesograzers fail to limit growth of macroalgae or their epiphytes in a temperate algal bed. J Ecol 97:164-175

Preen A (1995) Impacts of dugong foraging on seagrass habitats: observational and experimental evidence for cultivation grazing. Mar Ecol Prog Ser 124:201-213

Roelfsema C, Kovacs EM, Saunders MI, Phinn S, Lyons M, Maxwell P (2013) Challenges of remote sensing for quantifying changes in large complex seagrass environments. Estuar Coast Shelf Sci 133:161-171

Sanchez-Jerez P, Gillanders BM, Kingsford MJ (2002) Spatial variation in abundance of prey and diet of trumpeter (Pelates sexlineatus: Teraponidae) associated with Zostera capricorni seagrass meadows. Austral Ecol 27: 200-210

Editorial responsibility: Kenneth Heck Jr., Dauphin Island, Alabama, USA
Skilleter GA, Olds A, Loneragan NR, Zharikov Y (2005) The value of patches of intertidal seagrass to prawns depends on their proximity to mangroves. Mar Biol 147:353-365

Svensson CJ, Baden S, Moksnes PO, Aberg P (2012) Temporal mismatches in predator-herbivore abundance control algal blooms in nutrient-enriched seagrass ecosystems. Mar Ecol Prog Ser 471:61-71

Tibbetts IR, Connolly RM (1998) The nekton of Moreton Bay. In: Tibbetts IR, Hall NJ, Dennison WC (eds) Moreton Bay and catchment. University of Queensland, Brisbane, p 395-420

Udy JW, Dennison WC (1997) Physiological responses of seagrasses used to identify anthropogenic nutrient inputs. Mar Freshw Res 48:605-614

Unsworth RKF, Cullen LC (2010) Recognising the necessity for Indo-Pacific seagrass conservation. Conserv Lett 3: 63-73

Unsworth RKF, Taylor JD, Powell A, Bell JJ, Smith DJ (2007) The contribution of scarid herbivory to seagrass ecosystem dynamics in the Indo-Pacific. Estuar Coast Shelf Sci 74:53-62

Valentine JF, Duffy JE (2006). The central role of grazing in seagrass ecology. In: Larkum AW, Orth RJ, Duarte M (eds) Seagrasses: biology, ecology and conservation. Springer, Dordrecht, p 463-501

Valentine JF, Heck KL Jr, Busby J, Webb D (1997) Experimental evidence that herbivory can increase shoot density in a subtropical turtlegrass (Thalassia testudinum) meadow. Oecologia 112:193-200

> Venables WN, Dichmont CM (2004) GLMs, GAMs and GLMMs: an overview of theory for applications in fisheries research. Fish Res 70:319-337

> Verges A, Alcoverro T, Romero J (2011) Plant defences and the role of epibiosis in mediating within-plant feeding choices of seagrass consumers. Oecologia 166:381-390

> Warburton K, Blaber SJM (1992) Patterns of recruitment and resource use in a shallow-water fish assemblage in Moreton Bay, Queensland. Mar Ecol Prog Ser 90: 113-126

> Waycott M, Longstaff BJ, Mellors J (2005) Seagrass population dynamics and water quality in the Great Barrier Reef region: a review and future research directions. Mar Pollut Bull 51:343-350

Waycott M, Duarte CM, Carruthers TJB, Orth RJ and others (2009) Accelerating loss of seagrasses across the globe threatens coastal ecosystems. Proc Natl Acad Sci USA 106:12377-12381

- Westera MB, Lavery PS (2006) A comparison of hole punch and needle punch methods for the measurement of seagrass productivity. Aquat Bot 85:267-269

Whalen MA, Duffy JE, Grace JB (2013) Temporal shifts in top-down vs. bottom-up control of epiphytic algae in a seagrass ecosystem. Ecology 94:510-520

Wolanski E (2014) Estuaries of Australia in 2050 and beyond. Series 'Estuaries of the world', Springer, Dordrecht

Zieman JC (1974) Methods for the study of the growth and production of turtle grass, Thalassia testudinum König. Aquaculture 4:139-14

Submitted: October 11, 2013; Accepted: June 3, 2014

Proofs received from author(s): September 1, 2014 